\title{
Tax Problems Incident to Divorce and Property Settlement
}

\author{
Harold G. Wren*
}

In how many lives does Love really play a dominant part? The average taxpayer is no more capable of a "grand passion" than of a grand opera.

-Israel Zangwill, Romeo and Juliet and Other Love Stories

$\mathrm{M}^{\mathrm{s}}$ OST DIVORCES today are arranged by negotiation between the attorneys of husband and wife. Lawyers must not only contend with the grand passions that arise in connection with the custody of children or attempts at reconciliation but, once the parties have determined upon a divorce, the role of the client as a taxpayer may become equally important. By keeping taxes in mind and exercising care in drafting, the parties' attorneys will usually produce a smaller tax burden on the now divided family unit. Once an agreement has been reached, it is submitted to the divorce court for its imprimatur, and the tax consequences flow from its enforcement. This article explores some of these consequences.

COMPARISON OF PRENUPTIAL AND POSTNUPTIAL CONTRACTS

The income tax is primarily concerned with business situations, where parties deal at arm's length and where there is a substantial amount of bargaining and an expectation of profit. By way of contrast, the estate and gift taxes involve family situations. Divorce and property settlement agreements fall midway between. In the usual divorce, there is a large amount of bargaining, and the parties deal with one another as adversaries. Counsel representing both sides seek solutions in the best interests of the now dissolved family umit.

The difference between the donative kind of transaction and the one that involves arm's length bargaining can be seen by comparing prenuptial and postnuptial contracts. In the former, a transfer by the bridegroom to his bride-to-be in exchange for the waiver of her marital rights is a taxable gift. In Merrill v. Fahs, ${ }^{1}$ for example, the taxpayer was an elderly Floridian who agreed to set up a $\$ 300,000$ trust for a showgirl, Kinta Desmare, in exchange for the rights that she might acquire by reason of their marriage.

* Professor of Law, School of Law, Southern Methodist University.

1324 U.S. 308 (1945). 
The taxpayer, in the words of Mr. Justice Frankfurter, "was a man of large resources, with cash and securities worth more than $\$ 5,000,000$, and Florida real estate valued at $\$ 135,000 \ldots$ [while] Miss Desmare's assets were negligible."2 The Court held that the relinquishment of marital rights by Miss Desmare did not constitute an adequate and full consideration in money or money's worth, and accordingly, the establishment of the trust was taxable as a gift.

Contrast this view with the attitude of the Commissioner, the courts, and Congress toward the applicability of the federal gift tax to a postnuptial property settlement. The Commissioner has ruled that payments attributable to the wife's support are not subject to the gift tax where a decree of divorce exists. ${ }^{3}$ The Supreme Court has held that the gift tax does not apply to any transfer of property where provision for such transfer is incorporated into a divorce decree. ${ }^{4}$ And Congress has provided that there will be no gift tax where there is a written agreement relative to marital and property rights, and divorce occurs within two years thereafter. 5 Thus, the bulk of the tax problems imcident to divorce and property settlement involve the federal imcome tax.

\section{II}

\section{ALIMONY INCLUSION AND DEDUCTION SECTIONS}

In the early case of Gould v. Gould, ${ }^{6}$ the Supreme Court held that alimony was not includible under the general definition of gross income and therefore not taxable to the wife who received it. Similarly, it was not deductible by the husband. Normally, of course, the husband would pay such sums out of income on which he had previously paid tax. In 1935, it was held that where the husband established a trust and directed the trustee to use a portion of the income to pay his alimony obligation, the trust income was taxable income to the husband. ${ }^{7}$

These holdings were changed by Congress in 1942 when it provided that under certain circumstances alimony would be taxable to the wife ${ }^{8}$ and deductible to the husband, ${ }^{9}$ and that trust income would be taxable to the wife

$2 I d$. at 309.

3 E.T. 19, 1946-2 CuM. Burr. 166.

4 Harris v. Commissioner, 340 U.S. 106 (1950).

5 INT. REv. CODE OF 1954, § 2516.

6245 U.S. 151 (1917).

7 Douglas v. Willcuts, 296 U.S. 1 (1935).

8 Int. Rev. Code of 1939, $\$ 22(\mathrm{k})$, added by ch. 619, $\$ 120(\mathrm{a}), 56$ Stat. 816 (1942) (now INT. REv. CODE OF 1954, § 71).

${ }^{9}$ Int. Rev. Code of $1939, \S 23(\mathrm{u})$, added by ch. $619, \$ 120(\mathrm{~b}), 56$ Stat. 817 (1942) (now INT. REv. CODE OF 1954, § 215). 
rather than to the husband to the extent that it was used to satisfy the husband's alimony obligation..$^{10}$ The deduction is allowable to the husband only if he itemizes his deductions, ${ }^{11}$ and if the payments are includible in the gross income of the wife. ${ }^{12}$ The obligation of the husband to make the payments must arise under (1) a divorce or separate maintenance decree or written instrument incident to such decree, ${ }^{13}$ (2) a written separation agreement, ${ }^{14}$ or (3) a decree of support. ${ }^{15}$

\section{A. Payments Under Decree of Divorce or Separate Maintenance or Written Instrument Incident Thereto}

Section 71(a) (1) of the Internal Revenue Code of 1954 provides:

[1] If a wife is divorced or legally separated from her husband under a decree of divorce, or of separate maintenance,

[2] the wife's gross income includes periodic payments (whether or not made at regular intervals)

[3] received after such decree

[4] in discharge of (or attributable to property transferred, in trust or otherwise, in discharge of) a legal obligation

[5] which, because of the marital or family relationship, is imposed on or incurred by the husband

[6] under the decree or under a written instrument incident to such divorce or separation. (Emphasis added.)

\section{A Decree of Divorce or Separate Maintenance}

Prior to 1954, a periodic payment had to be paid under a decree of divorce or separate inaintenance for it to qualify under the 1939 Code equivalent of section 71. Alimony pendente lite, ${ }^{16}$ payments under an inter-

${ }^{10}$ Int. Rev. Code of $1939, \S 171$, added by ch. $619, \S 120$ (c), 56 Stat. 817 (1942) (now INT. REv. CODE of 1954, § 682). For purposes of all these sections, the term "husband" is used to describe the one who pays the alimony, and the term "wife" to describe the recipient thereof. INT. REv. CODE of 1954, §7701 (a) (17).

11 The deduction is not allowable if the "standard deduction" is used. See INT. Rev. CoDE of $1954, \S \S 62,63$, and 141 .

12 INT. REv. CODE OF 1954, § 215 (a).

13 INT. REv. CODE OF 1954, § 71 (a) (1).

14 INT. REv. CodE of 1954, § 71(a) (2).

15 INT. Rev. CODE of 1954, \& 71 (a) (3).

16 Richardson v. Commissioner, 234 F.2d 248 (4th Cir. 1956); Joseph A. Fields, 14 T.C. 1202 (1950), aff'd without discussion of this point, 189 F.2d 950 (2d Cir. 1951); George D. Wick, 7 T.C. 723 (1946), aff'd, 161 F.2d 732 (3d Cir. 1947); Robert A. McKinney, 16 T.C. 916 (1951); Harry A. Paton, 25 P-E Tax Ct. Mem. 446 (1956); Hampton Leedom, 25 P-H Tax Ct. Mem. 952 (1956); Ray W. Droke, 22 P-H Tax Ct. Mem. 642 (1953); Flower v. United States, 52 Am. Fed.Tax R. 1383 (W.D.Pa. 1957). 
locutory divorce decree,$^{17}$ support payments, ${ }^{18}$ payments under a separation agreement ${ }^{19}$-all fell outside the scope of the statute. Such payments were neither income to the wife nor deductible by the husband. Under the present law, these payments qualify under other parts of section $71 .^{20}$

Payments under Mexican divorce decrees qualify under both the $1939^{21}$ and $1954^{22}$ Codes. Similarly, payments incident to a German annulment decree have been held taxable to the wife, and deductible by the husband. ${ }^{23}$ In short, the requirement that there be a decree of divorce or separate maintenance presents relatively few problems. The Commissioner will treat a particular proceeding as qualifying under the statute if it is tantamount to divorce or separate maintenance, even though local law may give it a different name.

\section{Periodic Payments}

For the payments from husband to wife to be deductible by him and taxable to her, they must be "periodic." They may be either (1) a definite amount for an indefinite period; (2) a definite amount for a definite period, if paid over more than ten years; (3) an indefinite alnount for an indefinite period; or (4) an indefinite amount for a definite period.

\section{a. A Definite Amount for an Indefinite Period}

Where the payments from husband to wife may terminate upon the death or remarriage of the wife, the payments will be "periodic," though

17 Commissioner v. Evans, 211 F.2d 378 (10th Cir. 1954) (holding that payments under Colorado interlocutory decree of divorce were not income to the wife).

18 Tressler v. Commissioner, 228 F.2d 356 (9th Cir. 1955); Charles M. Hendricks, 30 T.C. 1303 (1958); John B. Keleher, 25 T.C. 1154 (1956) ; Franl J. Kalchthaler, 7 T.C. 625 (1946); Anthony D. Christopher, 28 P-H Tax Ct. Mem. 449 (1959) (payments under support order nullified by divorce); Thomas A. Walston, 27 P-H Tax Ct. Mem. 610 (1958); Commissioner v. Rankin, 270 F.2d 160 (3d Cir. 1959) (holding that a "support and maintenance" order of a Pennsylvania Quarter Sessions Court does not effect a "legal separation" under Pennsylvania law); W.L.H. Bergen, 20 P-H Tax Ct. Mem. 791 (1951); John E. Clayton, Jr., 26 P-H Tax Ct. Mem. 697 (1957); Charles G. Brown, 18 P-H Tax Ct. Mem. 618 (1949); Angelo Frascone, 18 P-H Tax Ct. Mem. 329 (1949); Edward S. Gerrish, 22 P-H Tax Ct. Mem. 552 (1953); Isadore Goodman, 18 P-H Tax Ct. Mem. 474 (1949) ; Edgar Jodoin, 22 P-H Tax Ct. Mem. 958 (1953).

18 Portfolio v. United States, 127 Ct. Cl. 536, 118 F. Supp. 367, cert. denied, 348 U.S. 827 (1954) (payments under separation agreement following discontimuance of action of separate maintenance).

20 INT. REv. CODE OF 1954, \&71(a) (2) (written separation agreement) and $\$ 71$ (a) (3) (decree for support).

21 G.C.M. 25250, 1947-2 CoM. Buxc. 32 (payments under agreement pursuant to Mexican divorce by resident of state that probably would not recognize sueh a divorce decree held incident to divorce and deductible by husband, where parties relied on decree).

22 Rev. Rul. 57-113, 1957-1 CUM. Burc. 106.

23 Reginald B. Parsons, 21 P-H Tax Ct. Mem. 890 (1951). 
payable over a period of less than ten years. ${ }^{24}$ The Tax Court ${ }^{25}$ and the Third Circuit ${ }^{26}$ have drawn a distinction between those payments that are expressed in terms of a defimite amount for a given unit of time (e.g., so much per month), and those that are payments of a total amount spread over a period of time (e.g., a sum of $X$ dollars payable semi-annually). Despite the presence of contingencies in both cases, the latter were classified as installment payments. Such a distinction seems unwarranted, ${ }^{27}$ and the 1954 Code Regulations are to the contrary. ${ }^{28}$ Payments subject to contingencies imposed by local law"9 qualify as "periodic" in the same manner as payments subject to contingencies imposed by the decree.

\section{b. A Definite Amount for a Definite Period, If Paid Over More Than Ten Years}

Section 71(c) (1) of the 1954 Code provides that installment payments shall not be treated as periodic payments. Although the statute does not define "installment payments," it does provide that if such payments are to be paid over a period of more than ten years they will be treated as "periodic payments" for purposes of section 71(a). ${ }^{30}$ It follows that amounts to be paid over less than ten years, not subject to any contingency,

24 Treas. Reg. § 1.71-(d) (3) (i) (a) (1957); Baker v. Commissioner, 205 F.2d 369 (2d Cir. 1953) ; Davidson v. Commissioner, 219 F.2d 147 (9th Cir. 1955); Prewett v. Commissioner, 221 F.2d 250 (8th Cir. 1955) ; Rev. Rul. 59-45, 1959-1 Cur. BuLr. 666 (ruling that payments made under a decree over a period of less than ten years, subject to the contingency of death, remarriage, or change of economic status of either spouse, qualify under both 1939 and 1954 Codes). But of. the following cases under the 1939 Code, holding that payments subject to a contingency may be installments: Clark J. Baker, 23 T.C. 161 (1954); Harold M. Fleming, 14 T.C. 1308 (1950) ; Estate of Frank P. Orsatti, 12 T.C. 188 (1949) ; Horace M. Read, 20 P-H Tax Ct. Mem. 368 (1951) ; W. B. Brandt, 19 P-H Tax Ct. Mem. 1020 (1950).

25 J. B. Stemel, 10 T.C. 409 (1948) ; Frank R. Casey, 12 T.C. 224 (1949); John A. Isfalt, 24 T.C. 497 (1955), remanded to vacate decision, 4 P-H 1956 FED. TAX SERv. II 71057 (7th Cir. 1956).

26 Estate of Smith v. Commissioner, 208 F.2d 349 (3d Cir. 1953) (distinction drawn between a payment of $\$ 300$ per month for five years and a sum of $\$ 25,000$ payable in ten semiannual installments).

27 Birdwell v. Commissioner, 235 F.2d 112 (5th Cir. 1956) (liolding that payments in discharge of principal sum fixed in decree were periodic where contingent on wife's marital status); Frazier v. United States, 48 Am. Fed. Tax R. 1950 (E.D. Ark. 1955) (payments of $\$ 100$ per month in discharge of gross sum of $\$ 5,000$ fixed in decree Leld periodic); Burton v. United States, 139 F. Supp. 121 (D. Utah 1956).

28 Treas. Reg. $\$ 1.71-1$ (d) (3) (ii) (b) (1957).

20 Treas. Reg. $\$ 1.71-1$ (d) (3) (ii) (a) (1957); Rev. Rul. 59-190, 1959-1 CuM. BuLd. 23 (alimony payments terminable on death of either spouse under common-law principle in the state of Washington).

30 INT. REv. CODE OF 1954, \& 71(c) (2). 
are not "periodic payments." Nearly all of the cases so hold, ${ }^{31}$ and the Regulations support this position. ${ }^{32}$

However, in Myers v. Commissioner, ${ }^{33}$ the agreement pursuant to a California divorce provided:

The husband agrees to pay to the wife for her support, maintenance and care, and in consideration of her execution hereof, the sum of Two Hundred Fifty Dollars (\$250) a month, in advance, during the period commencing on June 1, 1945, and continuing until May 31, 1951, after which date the husband shall not be called upon or required to pay to the wife any amount for her support, maintenance and care. The remarriage of the wife shall not relieve the husband from the performance of his obligations in this paragraph contained. ${ }^{34}$

In the Tax Court, the husband contended that the payments were deductible by him since they might be terminated by the death of either spouse, but Judge Black held that, regardless of such contingencies, the payments were "installment payments" and nondeductible. ${ }^{35}$

The Ninth Circuit reversed and held:

The Tax Court's holdings were clearly erroneous. No principal sum was specified in the seventh paragraph of the agreement of June 1, 1945. Therefore the ... payments ... were not installment payments discharging a part of an obligation the principal sum of which was so specified. ${ }^{36}$

Judge Mathews' holding pays undue attention to formalism, but if section

31 Robert D. Stecker, 31 T.C. 749 (1959) (agreement to pay fixed sum within 40 months; payments not deductible on theory that husband's possible noncompliance with agreement might prolong period beyond ten years); Eugene I. Attebery, 27 P -H Tax Ct. Mem. 369 (1958) (possible delay by husband's failure to keep insurance pohicies in force thereby extending term of policies beyond 10 years does not make payments "periodic," since noncompliance with court orders is not a recognizable contingency under statute); Joseph D. Fox, 14 T.C. 1131 (1950) (payment to wife at time of decree; balance of principal sum to be held $\mathrm{m}$ escrow); Lemuel Alexander Carmichael, 14 T.C. 1356 (1950); Klemm v. United States, 52 Am. Fed. Tax R. 1513 (E.D. Wis. 1957) (mortgage payments; unpaid balance determined by divorce court's findings of fact); Edmund D. Steelman, 28 P-H Tax Ct. Mem. 365 (1959) (unpaid balance of mortgage payments not set forth in decree but readily ascertainable); Jolın B. Kelcher, 25 T.C. 1154 (1956) ( $\$ 60,000$ payable to wife on signing of decree or after 6 months, less $\$ 100$ weekly to be given to wife in the neantime); Hampton Leedom, 25 P-H Tax Ct. Mem. 952 (1956) (payments of one-half of proceeds of a contract payable to husband upon his retirement, in total amount of $\$ 45,000$, at a rate of $\$ 625$ monthly) ; Ned Fuller, 18 P-H Tax Ct. Mem. 779 (1949); Edwin T. Heath, 21 P-H Tax Ct. Mem. 417 (1952); Ashcraft v. Coinmissioner, 252 F.2d 200 (7th Cir. 1958). But see Myers v. Commissioner, discussed in text at note 33 infra.

32 Treas. Reg. $\$ 1.71-1$ (d) (5), example (3) (1957).

33212 F.2d 448 (9th Cir. 1954).

34 Id. at 449 .

35 Rudolf B. S. Myers, 21 P-H Tax Ct. Mem. 1033 (1952).

30212 F.2d 448, 450 (9th Cir. 1954). 
71 (c) (1) is read strictly, there would appear to be a requirement that a principal sum be specified before there could be "installment payments":

For purposes of subsection (a), installment payments discharging a part of an obligation the principal sum of which is, either in terms of money or property, specified in the decree, instrument or agreement shall not be treated as periodic payments. ${ }^{37}$

The Regulations, on the other hand, indicate that such specification is unnecessary, if the total amount can be calculated by other means. ${ }^{38}$

\section{c. An Indefinite Amount for an Indefinite Period}

Often, it is desirable to base the amount of the periodic payment on external criteria other than a dollar amount. For example, the husband may be under a duty to pay a certain percentage of his income to his wife. ${ }^{39}$ If such a payment is subject to contingencies such as death or remarriage, it is a fortiori "periodic," for the reasons discussed above applicable to definite amounts payable for an indefinite period.

\section{d. An Indefinite Amount for a Definite Period}

The question remains whether an indefinite amount that is payable for a definite period of less than ten years will be deductible to the husband and taxable to the wife. The cases generally indicate that it will be so treated. In Fidler v. Commissioner, ${ }^{40}$ for example, the husband agreed to pay the wife $\$ 300$ monthly for a period of four and one-half years, or a total of $\$ 16,200$, but if his radio contract was reduced or cancelled, he was to pay her less or nothing, with no requirement that he make up any arrears. The Ninth Circuit held that such payments were periodic. Similarly, where the husband was to pay the wife one-third of the first $\$ 12,000$ of his annual salary, and one-fourth of any excess over this amount, for a period of five years, the Tax Court held the payments were periodic. ${ }^{41}$ And where the husband is required to pay additional amounts to insure that the wife gets a guaranteed yield on certain securities transferred to her, such amounts are periodic, since they are payable only under certain specified or external conditions. ${ }^{42}$

37 INT. REv. CODE of 1954, §71(c) (1). (Emphasis added.)

38 See Treas. Reg. $\S 1.71-1$ (d) (5), example (3) (1957). See also Treas. Reg. $\S 1.71-1$

(d) (3) (ii) (b) (1957).

39 The use of percentages often makes possible an easier adjustment to changing conditions.

40231 F.2d 138 (9th Cir. 1956).

41 John H. Lee, 10 T.C. 834 (1948). See also Roland Keith Young, 10 T.C. 724 (1948) (amounts husband required to pay, dependent on his previous years' salary, held periodic).

42 Mahana v. United States, 115 Ct. Cl. 716, 88 F. Supp. 285, cert. denied, 339 U.S. 978 (1950); Jane C. Grant, 18 T.C. 1013 (1952), afjd without discussion of point, 209 F.2d 430 (2d Cir. 1953). 
In summary, to make the payments from husband to wife "periodic" for purposes of section 71, counsel should follow these rules:

1. Make the payments subject to cessation on certain contingencies, e.g., the death or remarriage of the wife. If contingencies are used, you may use a term that is less than ten years, and the payments will still be classed as "periodic."

2. Don't use a fixed sum to determine the amount of the payments. Use a definite amount for an indefimite period or, better still, base the amount the wife is to receive on a fixed percentage of the husband's income.

3. If you must use a fixed sum, make sure that the payments extend over a period in excess of ten years, ${ }^{43}$ thereby qualifying thern under the statutory definition of "periodic."

4. Make provision for a reduction in the amount of the payments should the liusband be demed an mcome tax deduction for them.

\section{Received After Such Decree}

Under the 1939 Code, amounts paid by a husband to a wife under a decree of divorce or separate maintenance were deductible by the liusband and taxable to the wife, only when paid after the decree. Payments made prior to this time did not qualify under the 1939 Code equivalent of section 71(a)(1). In Warley v. McMahon, ${ }^{44}$ payments for periods prior to the decree, which were held in escrow and not paid until after the decree, were not deductible by the liusband. On the other hand, in B.R. DeWitt, ${ }^{46}$ the Tax Court held that alimony payments relating to a period prior to the decree but received thereafter were deductible by the liusband and taxable to the wife. On appeal, the Second Circuit reversed, ${ }^{46}$ following the earlier decision of the district court in Warley.

Under the 1954 Code, the problem of payments prior to the decree has been obviated by the provision in the Code allowing for payments under a written separation agreement to qualify under section $71 .^{47}$

43 The exact date upon which the husband's obligation becomes fixed is important. Compare Newman v. Commissioner, 248 F.2d 473 (8th Cir. 1957) (ten annual installments beginning with date of decree, rather than prior date of agreement, held payable in exactly ten ycars and not includible in wife's gross income), with Blum v. Commissioner, 177 F.2d 670 (7th Cir. 1949) (date of judge's signing of decree, rather than date of entering decree of record on the docket held controlling, thereby making payments extend for more than ten years). See Blum v. Commissioner, 187 F.2d 177 (7th Cir.1951) (relying on date of agreement as crucial date). Where only the month in which the first payment is to be made is specified, the last day of such month will be used to calculate the period over which the payments may be made. Compare United States v. Reis, 214 F.2d 327 (10th Cir. 1954) and Lillard v. Wiseman, 51 Am. Fed. Tax R. 1558 (W.D. Okla. 1956), with John A. Isfalt, 24 T.C. 497 (1955), remanded to vacate decision, 4 P-H 1956 Fed. TAX SERv. II 71057 (1956).

44148 F. Supp. 388 (S.D.N.Y. 1957).

4531 T.C. 554 (1958).

46 Commissioner v. DeWitt, 277 F.2d 720 (2d Cir. 1960) (one judge dissenting).

47 INT. REv. CODE OF 1954, 871 (a) (2). 


\section{In Discharge of a Legal Obligation}

Occasionally the question arises whether the husband is under a legal obligation to make the payments to the wife. In Maurice Fixler, ${ }^{48}$ for example, the husband, prior to the divorce, orally promised to pay the wife fifty dollars per week for the rest of her life. If she remarried, the payments would be reduced to twenty-five dollars per week. Relying on this oral agreement, the wife allowed a default to be entered against her in a suit for divorce on the grounds of adultery. The husband continued to make the weekly payments after the divorce, and five years later, the parties reduced the oral agreement to writing. The Commissioner argued that under these circumstances, the husband was under no legal obligation to make the payments, but the Tax Court held:

The oral agreement was made before the divorce and so at a time when Maurice was under an obligation pursuant to Illinois law to provide for his wife's support and maintenance. ...

The Mllinois law is settled that agreements of this kind are valid and survive divorce even though the grounds for the decree are the faults of the wife. ${ }^{49}$

Thus, the question of the existence of a legal obligation will normally be dependent on local law.

\section{Because of the Marital or Family Relationship}

To the extent that payments have been made as part of a settlement of community or partnership property, they are not "because of the marital or family relationship," and do not qualify under section 71.

\section{a. Community Property Settlements}

Where husband and wife divide their properties in a property settlement agreement, the portion the wife takes as her part of the property is not acquired "because of the marital or family relationship" since, under community property law, it already belongs to her. If the husband provides, in addition, payments for her support, this would be "because of the marital or family relationship." ${ }^{50}$ Unfortunately, many agreements fail to make

4825 T.C. 1313 (1956), acq., 1956-2 CUM. BULL. 5.

40 Id. at 1314.

50 That state law does not provide for alimony does not automatically make any payments from husband to wife part of a property settlement. If a wife gives up her support rights in exchange for a contractual right under an agreement, payments under the agreement are held to be in discharge of the husband's marital obligation. Brown v. Umited States, 121 F. Supp. 106 (N.D. Cal. 1954) ; Floyd H. Brown, 16 T.C. 623 (1951); Thomas E. Hogg, 13 T.C. 361 (1949), nonacq., 1950-1 Cux. BuLx. 7, dismissed on stipulation, 44 Am. Fed. Tax R. 1250 (5th Cir. 1951); Estate of Frances B. Willson, 26 P-H Tax Ct. Mem. 318 (1957); Arletta C. Harris, 21 P-E Tax Ct. Mem. 788 (1952). 
clear what portion is for her share of the community property, and what is for her support.

In Scofield v. Greer, ${ }^{51}$ the parties divided their community property, and the husband promised to make monthly payments to the wife, which were to cease if she remarried. The Fifth Circuit ruled that the payments were deductible by the husband and taxable to the wife, since "Dr. Greer intended to be and was obligated ... to make monthly support payments to Mrs. Greer so long as she remained unmarried." 152 It should be noted that the payments were in addition to the wife's share of the community property, and that the decree did not incorporate the agreement, although it did make reference to it.

In contrast with Greer is Campbell v. Lake..$^{53}$ In Lake the parties reached an agreement whereby the husband was to transfer to his wife $\$ 50,000 \mathrm{in}$ cash, plus some Arkansas realty worth $\$ 52,000$, and in addition pay her $\$ 1,000$ per month until he had paid a total of $\$ 125,000$. The agreement recited that "the money and property set apart to [the wife] ... and to be paid her in the future, is the value of the said Frances Peyton Lake's one-half of the community estate and is the most equitable manner of partitioming said community estate between the parties." was incorporated in full in the divorce decree. In the district court, Judge Atwell found that "the $\$ 12,000$ per year which she received from her former husband ... was required by the decree entered on that divorce bill and her settlement of property rights was not included in those payments of $\$ 12,000$ per year. The settlement of property rights was made outside of such $\$ 12,000$ per year. ${ }^{\prime 55}$ But the judge did not include this finding in his decree. Instead, he copied the contract of settlement in full into the decree and stated that "the property rights of the parties are hereby adjudged and decreed in conformity with said contract." ${ }^{\circ 0}$ On appeal to the Fifth Circuit, the husband sought to show that the test of Greer had been satisfied, since the payments were actually in addition to the property settlement; the recital in the agreement and the decree that they were in lieu of her share of the commumity property was simply to avoid the effect of local law which prohibited a concept of "alimony."

51185 F.2d 551 (5th Cir.), affirming 89 F. Supp. 75 (W.D. Tex. 1950).

$52185 \mathrm{~F} .2 \mathrm{~d}$ at 552 .

53220 F.2d 341 (5th Cir. 1955), reversing 45 Am. Fed. Tax R. 880 (N.D. Tex. 1953). Sce also John Sidney Thompson, 22 T.C. 275, dismissed on stipulation (5th Cir. 1954); Guggenheim v. Riddell, 1 Am. Fed. Tax R.2d 1799 (S.D. Cal.), rev'd on retrial on other grounds, 3 Am. Fed. Tax R.2d 373 (S.D. Cal. 1958).

$54220 \mathrm{~F} .2 \mathrm{~d}$ at 342 n.4.

$5545 \mathrm{Am}$. Fed. Tax R. at 880 .

56 Quoted at 220 F.2d at 344 .

${ }^{57}$ In Texas, the divorce court has no jurisdiction to provide permanent alimony. McBride v. McBride, 256 S.W.2d 250 (Tex. Civ. App. 1953). But see McElreath v. McElreath, .........Tex. 
Judge Hutcheson refused to accept the finding that the payments were outside of the property settlement in the face of the explicit statement in the agreement and decree that they were in lieu of the wife's share of the community property. He also noted that the payments were aggregated into a fixed sum that was payable absolutely and in all events, while in Greer, payments would cease upon Mrs. Greer's remarriage.

The recent case of Ann Hairston Ryker ${ }^{58}$ suggests ways to avoid the effects of Lake. In Ryker, the agreement provided that the husband was to pay the wife twenty-five per cent of his earnings and further stated: "Said payments are made as alimony and not as part of any settlement of property rights." and one month after the interlocutory decree, but were to cease upon the death or remarriage of the wife, or the death of the husband. Accordingly, the payments were "merely for the support of ... [the wife], in the nature of alimony," although the decree referred to them as being "in lieu of additional commumity property and as part of the consideration for the division of properties."

\section{b. Business Property Settlements}

Payments by the husband to his former wife, in discharge of an obligation arising out of a business relationship, may not be deducted by him, ${ }^{61}$ and are not included in the wife's mcome. ${ }^{62}$ The draftsman should state the precise nature of the obligation that the payments are to discharge, ${ }^{63}$ although such statement may not necessarily be controlling. ${ }^{\text {64 }}$

345 S.W.2d 722, 747 (1961), observing that "all provisions for 'wife support' are not invalid in Texas," and Bunker v. Bunker, 336 S.W.2d 751 (Tex. Civ. App. 1960) (writ dismissed), holding valid monthly payments to wife for bfe in lieu of lump sum settlement. However, the court can, and will, make provision for the wife and children by division of the property. It may make such division of the estate as it shall deem just and right, so long as title to realty is not divested. Tex. Rev. Crv. Stat. art. 4638 (1948). The division of the community need not be equal if circumstances justify awarding more than one-half to one spouse. Trimble v. Trimble, 15 Tex. 18 (1855). The court may, in a proper case, require one spouse to turn over his separate property to the other. Hedtke v. Hedtke, 112 Tex. 404, 248 S.W. 21 (1923).

5833 T.C. 924 (1960).

50 Quoted at 33 T.C. 925.

6033 T.C. at 929.

61 Thorsness v. United States, 260 F.2d 341 (7th Cir. 1958) (payments for all wife's rights "including claim for accounting").

62 Miriam Finley Schwartz, 23 P-H Tax. Ct. Mem. 509 (1954) (sum representing wife's share of damages recovered by jointly owned busimess is not alimony, where allocation of anticipated recovery is provided for in settlement agreement).

B3 Cf. Juha Nathan, 19 T.C. 865 (1953) (wife's claim of partnership disputed; no proof of value of business); United States v. Soltermann, 163 F. Supp. 397 (N.D. Cal. 1958) (wife's claim that payments represented property settlement of her rights in jewelry business rejected).

04 Landa v. Commissioner, 211 F.2d 46 (D.C. Cir. 1954) (liusband's oral testimony that payments were for wife's support held controlling, despite recital in agreement that payments were to discharge debt owed to wife). 


\section{Under a Decree or Written Instrument Incident to the Divorce or Separation}

The last requirement of section $71(a)(1)$ is that the payments be "under the decree or under a written instrument incident to such divorce or separation." Where the payments are "under the decree," no problem is presented, so long as the proceeding is a divorce or legal separation. ${ }^{65}$ But a number of cases have raised the question of whether the particular instrument was "incident" to the divorce or separation.

Under the 1939 Code and Regulations, the courts required that the agreement must stem from the decree. ${ }^{06}$ Incidence was found where there was (1) a discontinuance of legal action by the wife upon execution of an agreement, ${ }^{67}(2)$ an execution of an agreement thirteen days before the wife signed the divorce complaint, ${ }^{08}$ (3) an understanding that the agreement would determine support in the event of a later suit, ${ }^{60}$ (4) a reference to the agreement in the divorce decree, ${ }^{70}(5)$ an understanding that the agreement would be held in escrow until the divorce, ${ }^{71}$ or (6) testimony indicating the existence of an agreement during the divorce suit. ${ }^{\mathbf{7 2}}$

In time, the courts eroded away a strict requirement of incidence. Some of this hiberality was attributable to a desire to reach uniform tax results, despite local law prohibitions. Agreements qualified, although the local law forbade alimony. ${ }^{73}$ Where the local law invalidated agreements in contemplation of divorce, the tax law held that the incidence requirement was met, even though the agreement ignored the possibility of a later divorce or even stated that such a suit was not anticipated." Testimony that the parties

65 See discussion in text supra at notes 16-23.

OB Cox v. Commissioner, 176 F.2d 226 (3d Cir. 1949) (payments under agreement made after divorce and after husband's remarriage to discourage former wife from contesting divorce decree); Commissioner v. Walsh, 183 F.2d 803 (D.C. Cir. 1950) (payments under agreement not enforceable as part of divorce decree under California law) ; Frederick S. Dauwalter, 9 T.C. 580 (1947), appeal dismissed, 5 P-H 1948 Fed. Tax Serv. If 71052 (2d Cir. 1948); Jessie L. Fry, 13 T.C. 658 (1949).

67 Olga DeBelaieff, 25 P-H Tax Ct. Mem. 1165 (1959), appeal dismissed, (5th Cir. 1957); Du Pont v. United States, 122 Ct. Cl. 594, 104 F. Supp. 978 (1952).

68 Malıana v. United States, 115 Ct. Cl. 716, 88 F. Supp. 285, cert. denied, 339 U.S. 978 (1950).

${ }^{09}$ Bertha McKay Pease, 26 T.C. 749 (1956).

${ }^{70}$ Scofield v. Greer, 185 F.2d 551 (5th Cir.), affirming 89 F. Supp. 75 (W.D. Tex. 1950); Commissioner v. Murray, 174 F.2d 816 (2d Cir. 1949); Lilian Bond Smith, 21 T.C. 353 (1953), dismissed on agreed motion, (9th Cir. 1954).

71 Elizabeth E. Guggenheim, 16 T.C. 1561 (1951).

72 Estate of Frank H. Short, 19 P-H Tax Ct. Mem. 691 (1950).

73 Johnson v. Gill, 51 Am. Fed. Tax R. 1191 (M.D.N.C. 1956); Tuckie G. Hesse, 7 T.C. 700 (1946); Frank M. Hesse, 15 P-H Tax Ct. Mem. 739 (1946) ; see Scofield v. Greer, 185 F.2d 551 (5th Cir. 1950).

74 George T. Brady, 10 T.C. 1192 (1948); Robert Wood Johnson, 10 T.C. 647 (1948); Bertram G. Zilmer, 16 T.C. 365 (1951); Robert L. Montgomery, Jr., 23 P-F Tax Ct. Mom. 567 (1954). But cf. Francis Hamer Johnson, 21 T.C. 371 (1953), nonacq., 1958-2 CuM. Buxc. 9 (acq., 1954-1 Cus. BuLc. 5, withdraton). 
did not intend to secure a divorce at the time of the agreement did not prevent the agreement from being incident to the divorce. ${ }^{75}$

Another area in which the incidence requirement became less significant involved post-divorce revisions of pre-divorce agreements ${ }^{76}$ In Newton $v$. Pedrick, ${ }^{77}$ the Second Circuit considered the question of whether a divorced husband could deduct support payments made to his ex-wife under a postdivorce agreement when such payments were in addition to amounts payable under the original agreement made prior to the divorce. In finding that the later agreement was "imcident" to the divorce, Judge Harlan reasoned that the statute was concerned with the incidence of the agreement to the status of divorce, not to the decree of divorce.

With the adoption of status as the determinant of incidence, the trend toward hiberality has continued. In Hollander v. Commissioner ${ }^{78}$ the Ninth Circuit held that a post-divorce alteration of the agreement to allow the ex-wife to continue to receive payments after her remarriage was incident to the divorce.

In his Regulations ${ }^{79}$ and some recent rulings ${ }^{80}$ the Commissioner has indicated his intention to follow Nereton and Hollander, using the criterion of status. As a result, the incidence requirement is now easily satisfied.

75 Feinberg v. Commissioner, 198 F.2d 260 (3d Cir. 1952) (payments under Florida divorce decree qualified, though New York court later declared parties still legally married); Izrastzoff v. Commissioner, 193 F.2d 625 (2d Cir. 1952); Lerner v. Commissioner, 195 F.2d 296 (2d Cir. 1952) (payments under New York separation agreement, which survived New York divorce); Commissioner v. Miller, 199 F.2d 597 (9th Cir. 1952) (divorce not contemplated at time of California property settlement agreement, though agreement provided for survival of settlement in event of divorce); Commissioner v. Moses, 214 F.2d 912 (2d Cir. 1954); Stewart v. Rothensies, 114 F. Supp. 497 (E.D.Pa. 1953); Estate of Albert Moses, 22 P-H Tax Ct. Mem. 657 (1953), vacated and remanded per stipulation, 48 Am. Fed. Tax R. 1745 (2d Cir. 1955).

76 Smith v. Commissioner, 192 F.2d 841 (1st Cir. 1951) (payments under 1944 revision of 1937 agreement incorporated by reference into 1938 divorce); Muriel Dodge Neeman, 13 T.C. 397 (1949), afj'd, 200 F.2d 560 (2d Cir. 1952), cert. denied, 345 U.S. 956 (1953) (amendment of prior agrecment, which is not incident, by later incident agreement, makes whole agreement incident to divorce) ; Floyd W. Jefferson, 13 T.C. 1092 (1949) (letter to wife revising agreement held to be an agreement incident to divorce); Maurice Fixler, 25 T.C. 1313 (1956) (oral agreement later reduced to writing held mcident); Rowena S. Barnum, 19 T.C. 401 (1952) (agreement entered into 19 years after divorce in settlement of a dispute in respect to alimony provided by divorce decree and prior agreements incident thereto); Walsh v. Westover, $45 \mathrm{Am}$. Fed. Tax R. 877 (S.D. Cal. 1953).

77212 F.2d 357 (2d Cir. 1954). See also Holt v. Commissioner, 226 F.2d 757 (2d Cir. 1955), cert. denied, 350 U.S. 982 (1956) ; Heath v. Commissioner, 265 F.2d 662 (2d Cir. 1959), afirming 30 T.C. 339 (1958) ; Raoul Walsh, 21 T.C. 1063 (1954); Charles Campbell, 15 T.C. 355 (1950).

78248 F.2d 523 (9th Cir. 1957).

79 Treas. Reg. § 1.71-1(b) (1) (1957).

80 Rev. Rul. 58-152, 1958-1 Cum. Burc. 32 (modification of judgment nisi, predicated on written agreement, held incident to divorce) ; Rev. Rul. 58-451, 1958-2 CUM. BuLr. 914 (written instrument need not be in contemplation of divorce; payments deductible if made under instrument incident to status of divorce) ; Rev. Rul. 60-140, 1960-1 Conr. Bunc. 31 (announcing that service will follow Newton and Hollander where post-divorce amendments of predivorce agreements are involved); Rev. Rul. 60-141, 1960-1 Con. BuLc. 33 (same, where payments increased because of changed economic circumstances). 


\section{B. Payments Under a Written Separation Agreement}

\section{In Common-Law Jurisdictions}

Under the 1939 Code, payments under a written separation agreement were neither deductible by the husband nor income to the wife. Under present law, if a wife is separated from her husband, periodic payments under a written separation agreement executed after August 16, 1954, are taxed to the wife and deductible by the husband, whether or not the instrument is enforceable or the parties are subsequently divorced or legally separated. ${ }^{81}$ The parties must not file a joint return and the wife must receive the payments after the agreement's execution. ${ }^{82}$ The payments must be made because of the marital or family relationship, and if the parties are later divorced or legally separated, the payments will continue to be taxed to the wife under section 71 (a) (2) ${ }^{83}$ A pre-1954 agreement may be modified to bring it within the new rule. ${ }^{84}$

\section{In Community Property Jurisdictions}

Section 71(a) (2) has only a small area of operation in community property states, since few items may fall in the category of separate income. In Texas, for example, oil and gas royalties from separate property and capital gains on separate property constitute separate income, ${ }^{85}$ but income from separate property generally is community income. In California, income from separate property is separate income, and the possible area of operation is somewhat broader.

If the husband makes payments to the wife from such separate income, the parties may file separate returns, with the husband's return showing this separate income with a deduction for any payments made to the wife, and the wife's return showing the payments as income to her.

So far as community income is concerned, husband and wife may file separate returns in which they each report one-half of the total community income. The principal difficulty in this area is that the separation of husband and wife often makes it difficult for each of them to obtain the necessary tax information from the other. If a woman is deserted by her husband, she may remain liable for the tax on one-half of the income that he is earning, although she may have no idea where he is living. Under these circumstances, she should file as complete a return as possible, disclosing her name and address, and the last known address of her absent husband. By filing

81 INT. Rev. CODE OF 1954, § 71 (a) (2).

82 Ibid.; Treas. Reg. $\$ 1.71-1$ (b) (2) (1957).

83 Treas. Reg. $\$ 1.71-1$ (b) (2) (1957).

84 Ibid.; Rev. Rul. 56-418, 1956-2 COM. BULL. 27.

85 For purposes of community property law Texas treats these as capital, rather than income, items. 
such a return she can at least cause the statute of limitations to begin running. ${ }^{86}$

In the meanwhile the husband is required to file a return only on onehalf of the community income. If he erroneously includes his wife's share of the commumity imcome in his return, he may be entitled to a refund, and the wife may have a deficiency assessed against her. ${ }^{87}$ But while the wife may be responsible for the tax on her one-half of the husband's commumity earnings, by the same token she is entitled to a credit for one-half of the community taxes withheld..$^{88}$

The above problems may, of course, be avoided by the filing of a joint return. This will equalize both separate and community income to husband and wife for tax purposes, and the rule of section 71(a) (2) will not apply. ${ }^{89}$ In all events, counsel should consider the inclusion of a clause in the agreement that would require husband and wife to exchange tax information.

\section{Payments Under a Decree of Support}

\section{In Common-Law Jurisdictions}

Payments under a decree of support, like payments under a written separation agreement, were neither income to the wife nor deductible by the husband, according to the 1939 Code. Where a pre-1954 State court decree was held to be only an order of support, rather than a legal separation, the husband was not entitled to deduct the payments under the decree. ${ }^{\text {o0 }}$

Under present law, periodic payments for the support and maintenance of the wife made under a decree entered after March 1, 1954, are taxable to the wife and deductible by the husband. ${ }^{21}$ The parties must be living apart, and they must file separate returns. ${ }^{.2}$ Any decree that is modified by a court order entered after March 1, 1954, will be treated as a decree entered after such date, ${ }^{93}$ but the demial of a petition seeking increased payments pending litigation will not be treated as a modification. ${ }^{94}$ A non-support

80 $C f$. Elvina Ratto, 20 T.C. 785 (1953) (wife's return governed by five-year statute of limitations since gross incolne understated by $25 \%$ ).

87 Cf. Harold v. Commissioner, 232 F.2d 527 (9th Cir. 1956), holding that where husband's claim for refund was baseless, the deficiency assessed against the wife was invalid.

88 Donald W. Smith, 19 P-H Tax Ct. Mem. 816 (1950).

89 Two disadvantages of the joint return may be noted: (1) joint and several hability (even though the agreenent provides that the tax burden shall fall only on one spouse); and (2) the right of the spouse to inspect the return and thereby ohtain information that the other spouse might not wish him to have.

90 Russell W. Boettiger, 31 T.C. 477 (1958).

91 INT. REv. CODE OF 1954, § 71(a) (3).

82 Ibid.; Treas. Reg. \& 1.71-1(b)(3) (1957).

93 Treas. Reg. \& 1.71-1(b) (3) (ii) (1957).

94 Rev. Rul. 59-248, 1959-2 Cuar. Burl. 31. 
decree in the case of abandonment will qualify as a decree for support under section 71 (a) (3). ${ }^{95}$

\section{In Community Property Jurisdictions}

What we have said about payments by the husband to the wife under a written separation agreement applies equally to payments under a decree for her support. For example, though Texas does not recognize permanent alimony, the court may award temporary alimony pendente hite. ${ }^{08}$ In California, alimony payments under an interlocutory decree of divorce are now deductible by the liusband and taxable to the wife, in contrast with the rule under the 1939 Code.$^{97}$ As with payments under a written separation agreement, this presupposes that the payments are made out of the husband's separate income.

\section{Payments for Child Support}

Payments in support of minor children are neither deductible by the husband nor taxable to them. The husband may obtain a personal exemption deduction in the amount of $\$ 600$ for each child for whom he provides more than one-half of the support. ${ }^{98}$ To the extent that a decree, instrument, or agreement specifically indicates the proportion or dollar amount for the support of the husband's minor child, such amounts are not taxable to the wife. ${ }^{99}$ If no allocation is indicated, the whole sum is included in the wife's gross income. ${ }^{100}$ This is true even though she spends the whole amount received for the husband's minor children. ${ }^{101}$ If the wife receives support payments for a person other than such minor children, the payments are fully taxable to her, regardless of allocation. ${ }^{102}$ Where the amounts to be paid for the support of both the wife and the minor children have been specified, any payment less than the aggregate amount required by the instrument will be applied first to fulfill the amount payable to the children. Only the balance will be considered alimony to the wife. ${ }^{103}$

95 Rev. Rul. 58-321, 1958-1 CuM. Burd. 35.

96 Texas Rev. Crv. Stat. art. 4637 (1948).

${ }^{07}$ Rev. Rul. 57-368, 1957-2 CuM. BuLL. 896 (revoking I.T. 3761, 1945 CuM. Bunc. 76); Rev. Rul. 55-178, 1955-1 CZM. BuLL. 122; I.T. 3934, 1949-1 CuM. Bull. 54; I.T. 3944, 1949-1 Cư. Burr. 56.

98 INT. REv. CODE OF 1954, §§ 151, 152.

99 INT. REv. CODE OF 1954, § 71 (b); Commissioner v. Lester, 366 U.S. 299 (1961).

100 Treas. Reg. $\S 1.71-1$ (e) (1957); Commissioner v. Lester, supra note 99.

101 Francis Hummel, 28 T.C. 1131 (1957); Dora H. Moitoret, 7 T.C. 640 (1946); Elsa B. Chapin, 16 P-H Tax Ct. Mem. 782 (1947).

102 Treas. Reg. $\$ 1.71-1(\mathrm{e})(1957)$; Robert Lehman, 17 T.C. 652 (1951), appeal dismissed, 5 P-H 1952 Fed. Tax Serv. \ 71101 (2d Cir. 1952), acq., 1959-1 Cux. Burd. 4, (nonacq., 1952-1 Cusc. Buzx. 5, withdrazon) (wife's mother); Ruth Lamar Lehman, 24 P-H Tax Ct. Mem. 777 (1959), aff'd, 234 F.2d 958 (2d Cir. 1956). But cf. Mandel v. Commissioner, 229 F.2d 382 (7th Cir. 1956) (wife not taxed where she was conduit for payments to children who were no longer minors).

103 Treas. Reg. \& 1.71-1(e) (1957) ; Martha J. Blyth, 21 T.C. 275 (1953). 
The above rules indicate the necessity for careful drafting in order to fix the precise amounts that will be taxable to the wife. Where the instrument fails to indicate the precise allocation, the court may imply one, based on the language of the instrument.

\section{E. Other Considerations}

Additional matters that should be noted concerning the income tax effects of periodic payments may be summarized as follows:

1. Where the husband remarries and continues to make payments from the new community to his first wife, such payments may be deducted by both the husband and his second wife for purposes of the income tax..$^{104}$

2. Where a decree is entered nunc pro tunc, ${ }^{105}$ the benefits of sections 71 and 215 normally will not be applied retroactively. Since the law now permits a deduction where there is a written separation agreement even though there is no divorce decree, this problem has become less important in recent years.

3. The wife is on the cash basis for periodic payments although she may be on the accrual basis for other tax accounting purposes. Thus where the husband seeks to hquidate his arrearages and pays them off all in one year, it may cause a considerable bunching of income to the wife. ${ }^{108}$

4. Where a husband makes a lump sum settlement for both past due payments and future claims for support, the wife realizes income in the amount of the arrears. For example, suppose a husband is delinquent in the amount of $\$ 50,000$, and still owes $\$ 75,000$ in future payments. He settles both claims for $\$ 80,000$. The Service has taken the position that the entire $\$ 50,000$ is income to the wife..$^{107}$

\section{III}

\section{PROPERTY SETTLEMENTS}

The division of property between husband and wife when they are divorced inevitably raises questions of the gift, estate, and income tax effects of the settlement.

104 Commissioner v. Newcombe, 203 F.2d 128 (9th Cir. 1953) (applying California law); Robert A. Sharon, 10 T.C. 1177 (1948) (applying Texas law); Raoul Walsh, 21 T.C. 1063 (1954) (applying California law). Contra, Godchaux v. United States, 102 F. Supp. 255 (E.D. La. 1952) (applying Louisiana law).

105 Daine v. Commissioner, 168 F.2d 449 (2d Cir. 1948). But see Margaret Rice Sklar, 21 T.C. 349 (1953) and Velma B. Vargason, 22 T.C. 100 (1954), where the Tax Court allowed retroactive application for a nunc pro tunc entry to correct a mistake.

108 Grant v. Commissioner, 209 F.2d 430 (2d Cir. 1953) ; Gale v. Commissioner, 191 F.2d 79 (2d Cir. 1951); Antomette L. Holalian, 21 T.C. 451 (1954), aff'd, 222 F.2d 82 (2d Cir. 1955).

107 Private ruling, discussed in RICE, Fammy TAX Planning 428 (1960). The author

suggests that a proration device would be more equitable (e.g. $\frac{\$ 50,000}{\$ 50,000+\$ 75,000} \times \$ 80,000=$ $\$ 32,000=$ that portion of the total amount paid allocable to past paynents and therefore taxable to the wife). 


\section{A. Gift Tax Consequences}

Where there is an equal division of the community property and no separate property is involved, there is no gift tax for either spouse since there is no gift. ${ }^{108}$ But even if the division of the community is unequal, or if one spouse transfers separate property to the other, there will be no gift tax if the transfer is (1) made to satisfy an obligation of support, ${ }^{109}$ (2) incorporated into the divorce decree, ${ }^{110}$ or (3) made within two years prior to the divorce. ${ }^{111}$

Similarly, in common-law jurisdictions, there will be no gift tax in connection with the transfer of property from one spouse to another as part of a property settlement agreenent in conjunction with separation or divorce.

\section{B. Estate Tax Consequences}

Typically, there are few estate tax problems in property settlements. It is possible to restrict a transfer so that the property will be included in the gross estate, but proper drafting should avoid this problem. It is unlikely that such property would be included in the gross estate of the transferor as having been transferred in contemplation of death. ${ }^{112}$

More difficult problems arise when a deduction is sought for the exwife's claim agamst her former spouse's estate. If such claim is based on an agreement, it is non-deductible, since the release of marital rights does not constitute an adequate and full consideration in money or money's worth. ${ }^{113}$ But if the agreement is incorporated into the divorce decree, it is deductible. ${ }^{114}$ This is true even though the parties provide that the agree-

108 Norman Taurog, 11 T.C. 1016 (1948), non acq., 1949-1 Con. BuLx. 6, appeal dismissed, 5 P-H 1949 FED. TAX SERv. If 71097 (9th Cir. 1949).

109 Treas. Reg. § 25.2516-2 (1958) ; Paul Rosenthal, 23 P-H Tax Ct. Mem. 487 (1954).

110 Harris v. Commissioner, 340 U.S. 106 (1950) ; MeMurtry v. Commissioner, 203 F.2d 659 (1st Cir. 1953).

111 INr. REv. CoDE of 1954, § 2516. The 1954 Code has eliminated much of the earhier uncertainty of the case law. Hence, a transfer of securities to a trust for the benefit of taxpayer's divorced wife for life or until ber remarriage is not subject to gift tax where the trust is created pursuant to a property arrangement made prior to divorce. Rev. Rul, 57-506, 1957-2 CUIr. BULr. 65.

112 See Cowles v. United States, 152 F.2d 212 (2d Cir. 1945).

113 Rogan v. Riggle, 128 F.2d 118 (9th Cir. 1942); Chase Nat'l Bank v. Hickey, 30 Am. Fed. Tax R. 1685 (N.D.N.Y. 1942) ; Bank of New York v. Umited States, 115 F. Supp. 375 (S.D.N.Y. 1953) ; Estate of Rosalean B. Ottmann, 12 T.C. 1118 (1949); Cowles v. Umited States, 152 F.2d 212 (2d Cir. 1945); Nantke v. United States, 35 F. Supp. 450 (W.D.N.Y. 1940); Meyer's Estate v. Commissioner, 110 F.2d 36 7 (2d Cir.), cert. denied, 310 U.S. 651 (1940) ; Adriance v. Higgins, 113 F.2d 1013 (2d Cir. 1940) ; Estate of Robert Manning McKeon, 25 T.C. 697 (1956); International Trust Co. v. United States, 32 Am. Fed. Tax R. 1672 (D. Colo. 1943) ; Estate of Eben B. Phillips, 36 B.T.A. 752 (1937); Commissioner v. Weiser, 113 F.2d 486 (10th Cir. 1940); Estate of Chester H. Bowers, 23 T.C. 911 (1955).

114 Yoke v. Fleming, 145 F.2d 472 (4th Cir. 1944); Commissioner v. Maresi, 156 F.2d 929 (2d Cir. 1946); Edythe C. Young, 39 B.T.A. 230 (1939); Estate of Angus O. Swink, 14 P-H Tax Ct. Mem. 569 (1945), af'd, 155 F.2d 723 (4th Cir. 1946) ; Estate of Myles C. Watson, 
ment shall control their financial obligations, notwithstanding contrary provisions in the divorce decree. ${ }^{115}$ Arrearages for support payments are deductible in any event. ${ }^{116}$ Moreover, to the extent that the decree or agreement provides for the support of dependents other than the wife, there may be a deductible claim against the taxpayer's estate. ${ }^{117}$

A recent case indicates that substantial estate tax savings may be obtained by making dependents' claims enforceable against the husband's estate. Husband and wife entered into a property settlement agreement in which he agreed to deliver an instrument obligating him to leave one-half of his estate to his two sons. The instrument was to bind his estate wliether or not he executed a will with similar provisions. He delivered the instrument and subsequently died, leaving a will in which he devised and bequeathed one-half of his estate to his two sons. His executors paid $\$ 56,242.50$ to each of the sons and sought a deduction for these amounts. The district court held that the transfers were testamentary gifts and non-deductible. ${ }^{118}$ But the Third Circuit reversed, reasoning that since the sons could have recovered these amounts as creditors of the estate, the claims were deductible for estate tax purposes. ${ }^{119}$

The estate planning possibilities of this decision are amazing. For example, in a common-law jurisdiction, a husband desiring to transfer at death $\$ 56,242.50$ to each of two children could, by obligating himself to do so and by taking advantage of the marital deduction, transfer as much as $\$ 232,485.00$ estate tax free. In a commumity property state, the result would be the same if the decedent's estate were separate property. And if we assume that all or any part of his estate is community, the amount that he can transfer tax-free becomes even greater. If, for example, he obligates himself to transfer $\$ 56,242.50$ to eaclı son, and he later dies, leaving a comnunity estate of $\$ 344,970.00$, the entire estate passes free of estate tax.

20 T.C. 386 (1953), affd, 216 F.2d 941 (2d Cir. 1954); Commissioner v. State Street Trust Co., 128 F.2d 618 (1st Cir. 1942); Estate of Walter T. Keller, 11 P-H B.T.A. Mem. 216 (1942); Howard Ross, 9 P-H B.T.A. Mem. 24 (1940); Estate of Silas B. Mason, 43 B.T.A. 813 (1941), dismissed on joint motion, 30 Am. Fed. Tax R. 1613 (6th Cir. 1942); Estate of Reinhold H. Forstmann, 16 P-H Tax Ct. Mem. 129 (1947); Commissioner v. Estate of Shively, 276 F.2d 372 (2d Cir. 1960).

116 Commissioner v. Estate of Watson, 216 F.2d 941 (2d Cir. 1954). But see Estate of Chester H. Bowers, 23 T.C. 911 (1955).

116 E.T. 19, 1946-2 Cuar. BuLl. 166. Note, however, that there is no estate tax analogue for INT. REV. CoDE OF 1954, § 2516.

117 Commissioner v. Weiser, 113 F.2d 486 (10th Cir. 1940); Estate of Eben B. Phillips, 36 B.T.A. 752, 757 (1937). In both of these cases the wife's claim was held non-deductible. See also cases cited note 113 supra.

118 Beecher v. United States, 172 F. Supp. 323, motion to set aside judgment denied, 4 Am. Fed. Tax R. 2d 6101 (E.D. Pa. 1959).

119 Beecher v. United States, 280 F.2d 202 (3d Cir. 1960), cert. not sought by Commissioner, P-H 1960 FEd. TAX SERv. II 135903. 
This is because the full amount of his debt is a separate debt, which is fully deductible from his one-half of the community property. Thus, the more community property he owns at death, and the more he obligates himself to transfer at death to his children, the greater the amount of property he can transfer free of estate tax. The law is clear that such a contract to provide for his children at death is specifically enforceable. ${ }^{120}$

The question remains: How nuch is deductible? The following example will illustrate the problen:

$H$ and $W_{1}$ obtain a divorce in which $H$ promises to pay $W_{1}$ a certain sum for the rest of her life. He agrees that if he should predecease $W_{1}$ his estate will either (1) continue the payments for the balance of her hife, or (2) buy her an annuity that will provide the equivalent sum. After the divorce of $H$ and $W_{1}, H$ marries $W_{2} . H$ later dies. The value of future payments owing $W_{1}$ as of the date of $H$ 's death is $\$ 60,000$. The cost of an annuity to provide equivalent payments is $\$ 90,000$. How much of $W_{1}$ 's claim is deductible?

The law is clear that the commuted value of the estate's liability for future support payments, rather than the cost of the annuity, is the measure of the deduction. Accordingly, the most we could expect would be a deduction of $\$ 60,000$.

But this is deductible only if $H$ 's estate is liable for the entire amount. Since one-half of the claim is payable out of $W_{2}$ 's half of the community property, $H$ 's estate is limited to a deduction of one-half the claim, or $\$ 30,000$. If, however, $H$ directs in his will that any "personal"121 or separate debts shall be paid entirely out of his half of the community property, it would appear that the entire $\$ 60,000$ would be deductible from his gross estate, even though only one-half of the total community property is includible. Conversely, in the absence of such direction, with the possible exception of her special or reserved comnunity property, ${ }^{122}$ the wife's half

120 Thurman v. Fatherree, 325 S.W.2d 183 (Tex. Civ. App. 1959) (writ dismissed); In re Howe's Estate, 207 Misc. 972, 132 N.Y.S.2d 855 (Surr. Ct. 1954). Even in New Jersey, the only state where such agreements have been held not specifically enforceable, it has been held that a contract between husband and wife by which husband agreed to make a will in favor of his minor child was specifically enforceable by the minor child by her next friend. In modifying the decree below, the Court of Errors and Appeals specifically pointed out that there had heen no appeal from the provisions of the decree directing specific performance of the asserted undertaking to make a testamentary disposition in favor of the infant complainant. Harrington v. Harrington, 141 N.J. Eq. 456, 57 A.2d 542, modified on other grounds, 142 N.J. Eq. 684, 61 A.2d 466 (1948). Courts have zealously enforced the father's obligation to support his minor children. See, e.g., Hartman v. Hartman, 138 S.W.2d 802 (Tex. Comm. App. 1940). See generally, Annot., 44 A.L.R.2d 1091 (1955).

121 United States v. Goodyear, 99 F.2d 523 (9th Cir. 1938) ("personal" debts of $H$ held fully deductible though only one-half of total community property includible in H's gross estate).

122 Illich v. Household Furniture Co., 103 S.W.2d 873 (Tex. Civ. App. 1937) (writ refused). But see Crim v. Austin, 6 S.W.2d 348 (Tex. Comm. App. 1928) (implying the 
of the community property may be reached for the husband's separate debts. ${ }^{123}$ Where the husband leaves separate property, it should first be marshalled to pay any antenuptial debts, such as the claim of $W_{1}{ }^{124}$ Accordingly, the draftsman of $H$ 's will should provide that any claim of $W_{1}$ should first be satisfied out of $H$ 's separate property, and to the extent that this is insufficient to pay the claim, any deficiency should be paid entirely out of $B$ 's half of the community property.

For income tax purposes, periodic payments to $W_{1}$ out of community income are deductible by both $H$ and $W_{2}$. It is equally clear that $H$ 's personal representative may deduct periodic payments on the income tax return of $H$ 's estate. ${ }^{125}$ It is immaterial that the value of the claim is also deductible for estate tax purposes.

\section{Income Tax Consequences}

\section{Possibilities of Taxable Exchange with Establishment of New Basis}

In antenuptial transactions, the problems of tax planning are the same in community property states as in common-law jurisdictions. The husband typically transfers property to the wife in exchange for her release of marital rights. Since the promise is not an adequate and full consideration in money or money's worth, the transfer is subject to the gift tax, ${ }^{126}$ and the basis of the transferor goes over to the transferee. ${ }^{127}$ Since 1948, husbands have wisely waited until after the marriage to make the gift, in order to take advantage of the marital deduction. ${ }^{128}$

contrary). See Cad. Crv. Code §168. Compare CaL. Crv. Code §171c, with Cat. Prob. CODE $§ 202$.

123 Estate of Coffee, 19 Cal. 2d 248, 120 P.2d 661 (1941); Estate of Algee, 158 Cal. App. 2d 691, 323 P.2d 221 (1958); Portis v. Parker 22 Tex. 699 (1859); Lee v. Henderson, 75 Tex. 190, 12 S.W. 981 (1889); Crim v. Austin, 6 S.W.2d 348 (Tex. Comm. App. 1928); CaL. Prob. CODE $§ 202$.

124 See Portis v. Parker, 22 Tex. 699, 705 (1859), where the court said: "where there were both community property and separate estates of husband and wife, the Spanish law charged the community debts upon the conmunity property; but we were not satisfied that the community property was not liable ... for the separate debts of the husband when he had no separate estate out of which such debts could be discharged."

${ }^{125}$ Laughlin's Estate v. Commissioner, 167 F.2d 828 (9th Cir. 1948). The income is taxable to the wife. Helen Scott Fairbanks, 15 T.C. 62 (1950), affd, 191 F.2d 680 (9th Cir. 1951), cert. denied, 343 U.S. 915 (1952); Alice M. Townsend, 12 T.C. 692 (1949), aff'd, 181 F.2d 502 (6th Cir. 1950).

128 Commissioner v. Wemyss, 324 U.S. 303 (1945); Merrill v. Fahs, 324 U.S. 308 (1945).

127 Homer H. Marshman, 31 T.C. 269 (1958), rev'd on other grounds, 279 F.2d 27 (6th Cir. 1960). See also Dunn v. United States, 86 F. Supp. 861 (E.D. Pa. 1949); Alice M. Townsend, 12 T.C. 692 (1949), aff'd, 181 F.2d 502 (6th Cir. 1950). Contra, Farid-Es-Sultaneh v. Commissioner, 160 F.2d 812 (2d Cir. 1947) (holding 2-1 that the wife takes a stepped-up basis at the time of the transfer).

128 In a commumity property jurisdiction the property so transferred would normally be the husband's separate property. 
In postnuptial transactions, the tax treatment varies depending upon whether community property is involved. In common-law jurisdictions, transfers in satisfaction of the wife's right of support are not subject to gift tax. ${ }^{129}$ Until recently, it was thought that the husband realized gain to the extent that the value of the wife's release of her right of support exceeded his basis in the property transferred..$^{130}$

In the recent case of Commissioner v. Marshman, ${ }^{131}$ the Sixth Circuit refused to follow the Second and Third Circuits, which had previously held that the value of what the husband receives is measured by the value of the property he transfers. In Marshman, the court said:

Section 111 (b) [of the Internal Revenue Code of 1939] requires that the capital gain be ineasured by 'the fair market value of the property ... received' (emphasis added) by the taxpayer, not by the fair market value of the property transferred by the taxpayer in exchange for the property received. To say that the fair market value of the property received is the same as the fair market value of the property given up not only ignores realities, but is the use of a formula which is radically different from the well-established and well-recognized formula approved by the courts for determining fair market value ....

Unfortunately, it is often the case that what a husband transfers to his wife in a so-called property settlement in a pending divorce action is not given merely in exchange for a release of alinony and dower rights, but also includes, without being so labeled, such additional amount as the husband may be willing to pay in order to have the marriage status terminated. ... The value of what is given up is no criterion of the fair market value of the 'property' received. ${ }^{132}$

The Court of Claims recently discussed the conflict among the circuits and concluded that Marshman stated the correct rule. ${ }^{133}$ If no gain is recognized upon the transfer of the appreciated property, it follows that the wife will take the husband's basis in the property. ${ }^{134}$ Should the parties desire to obtain a stepped-up basis for the wife, it is, of course, possible for them to make an agreement establishing the value of the release of her rights of support, and this presumably would be controlling. ${ }^{135}$

129 See text at notes 1-5 supra.

130 Commissioner v. Mesta, 123 F.2d 986 (3d Cir. 1941), cert. denied, 316 U.S. 695 (1942) (securities); Commissioner v. Halliwell, 131 F.2d 642 (2d Cir. 1942), cert. denied, 319 U.S. 741 (1943) (securities) ; E. Eugene King, 31 T.C. 108 (1958), appeal dismissed per stipulation, (9th Cir. 1959) (life estate in ranch property).

131279 F.2d 27 (6th Cir.), cert. denied on taxpayer's application, 364 U.S. 918 (1960), reversing and remanding Estate of Gordon A. Stouffer, 30 T.C. 1244 (1958).

132279 F.2d 27, 32.

133 Davis v. United States, 287 F.2d 168 (Ct. Cl. 1961). The Government has decided to seek certiorari, (May 29, 1961); and see note 169 infra.

134 Commissioner v. Marshman, 279 F.2d 27, 34 (6th Cir.), cert. denied on taxpayer's application, 364 U.S. 918 (1960). But cf. Commissioner v. Patino, 186 F.2d 962 (4th Cir. 1950); Edna W. Gardner Trust, 20 T.C. 885 (1953).

135 Cf. Aleda N. Hall, 9 T.C. 53 (1947). 
If the transfer of property in exchange for release of rights of support is viewed as an exchange, it is arguable that the wife realizes gain to the extent that the fair market value of what she receives (the property) exceeds the basis (normally zero) of what she gives up (her right of support), but there are no cases directly so holding. ${ }^{138}$

In community property jurisdictions, these principles apply to transfers by the husband of separate property. ${ }^{137}$ If the transfer involves an equal division of each piece of the community property, there is no sale or exchange, since each spouse takes what is already his. But such a settlement is rarely convenient or equitable. Typically, the parties agree to an equal division of the total community property and then assign certain properties to the husband and other properties to the wife. Such a division does not involve a realization of gain or loss to either party. The basis to the community in various parcels is reassigned to the husband and wife according to relative bases of fair market values. But where there is an unequal division of the comniunity property or where the husband transfers a large anount of cash to the wife for her share of the community, there is a taxable transaction.

An example of the problems that arise from unequal community property divisions is Johnson $v$. United States. ${ }^{138}$ The parties, domiciled in California, arranged for a purportedly equal division of the community property. As part of the division, the wife transferred to the husband her one-half interest in certain accrued fees that her husband, an attorney, had earned but had not received. In their income tax returns the husband and wife each treated one-half of the fees as income. The Commissioner found that the full aniount of the earnings was taxable income to the husband and none was taxable to the wife. He therefore granted a refund to the wife and assessed a deficiency against the husband. The district court agreed, reasoning that since the fees were collected after the divorce and the husband was on the cash basis, they were the husband's separate property and the full amount was taxable to him. He was entitled to no deduction and the wife realized no income.

On the husband's appeal the Ninth Circuit reversed, holding that under

136 Cf. Farid-Es-Sultaneh v. Commissioner, 160 F.2d 812 (2d Cir. 1947), note 127 supra.

137 As mentioned at note 57 supra, the divorce court might require a transfer of separate property in order to achieve an equitable division of property. In community property jurisdictions the practice varies. See, e.g., Fox v. Fox, is Cal.2d 645, 117 P.2d 325 (1941); Arrz. REv. STAT. ANN. § 25-318 (1956) (divorce court has no authority to require transfer of separate property). Contra, Nev. Rev. Star. $\$ 125.150$ (2) (Supp. 1959). In any event the parties may agree on a transfer of separate property. To the extent that a property settlement is a "bargained-for transaction" as distinct from "a partition or division of community property," gain or loss is recognized with resulting adjustments in basis. Robert S. Howard, 32 T.C. 1284 (1959), acq., 5 P-H 1960 FED. TAX SERv. \I 54955.

138135 F.2d 125 (9th Cir. 1943). See also Ione C. Hubner, 28 T.C. 1150 (1957). 
the principles of Helvering $v$. Horst ${ }^{139}$ the wife could not transfer income that was attributable to her. The husband was therefore entitled to a refund of the deficiency assessinent. Had the Ninth Circuit stopped at this point the decision in Johnson would be of little interest to us. But the court also held that the annount of the husband's refund should be reduced by the amount of tax allocable to the gain that he realized on the "exchange of community assets." ${ }^{140}$ Judge Denman stated:

"Here was soniething more than a mere division of property. The appellant admits that in the transaction so dealing in property he made a gain of over two thousand dollars. We regard it as a taxable gain .... Cf. Commissioner v. Mesta." $" 141$

The next case to consider the income tax consequences of a division of commumity property, C.C. Rouse, arose in Texas. ${ }^{142}$ Husband and wife owned properties as follows:

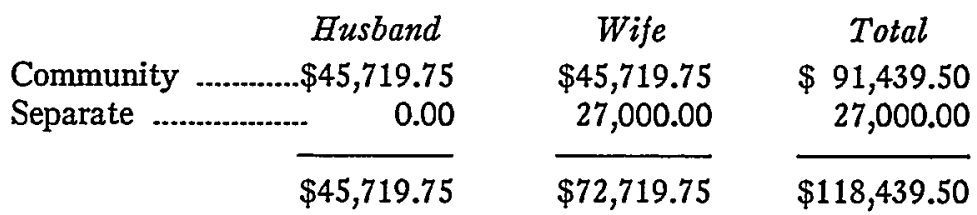

The agreeinent between them provided that the husband should transfer cash or property to the wife so that she would realize a total of $\$ 60,000$, plus $\$ 722.39$ of an income tax debt, which he would pay for her. On a subsequent disposition of property acquired in the settlement the husband urged that his basis should be that of the community, but both the Tax Court and the Fifth Circuit held that the transaction was a sale and purchase of the wife's half of the community property. The husband's basis was therefore determined by the cost of this interest to him. His cost was computed by subtracting the value of the wife's separate property $(\$ 27,000)$ from $\$ 60,722.39$, the amount that he gave up in the settlement. The Tax Court noted the fine line between property division and purchase and sale:

Such property settlements are arm's length transactions, valid in all respects. They result in the transfer of property rights or interests for a consideration, and there is no sufficient reason to distinguish them from any other transactions fundamentally sinilar. If there were simply a division of the community estate, as petitioner contends, the property would have been equally divided, or at least an attempt would have been made in good faith to achieve an equal division. In that event, where, in exchange for a vested undivided one-half interest in the whole, each party receives

139311 U.S. 112 (1940).

140135 F.2d 125, 130.

141 Ibid.

1426 T.C. 908 (1946), aff'd, 159 F.2d 706 (5th Cir. 1947). 
a vested interest in the whole of one-half, obviously there would be no resulting taxable gain, and no change in the basis of any of the property by reason of the settlement. But where, as here, there results a virtual sale of one interest, whatever tax consequences flow from the amount of the consideration should be given proper effect. ${ }^{143}$

The use of the $\$ 60,000$ figure in Rouse as the basis for settlement made the transaction appear to be a sale and purchase, rather than a division of property. Working out a settlement on these particular facts was complicated because the wife owned $\$ 27,000$ of separate property, which could not be traced to any specific property. The parties calculated the value of the community property by adding up all asset values and then deducting the value of her separate property from the total so derived. Had they been able to separate out the wife's separate property, the solution would have been much simpler.

In Long v. Commissioner ${ }^{144}$ the property settlement agreement provided for an optional arrangement whereby the husband would either allow the wife to take one-third of all the community property, or provide her with annuities that would furnish her a total of $\$ 200$ per month for the rest of her life. The husband chose to do the latter, and the court ruled that it was a purchase of a portion of the wife's community property, rather than a division of property. The husband therefore was entitled to set up as a cost base a pro rata portion of the fair market value of the annuity.

A large cash transfer caused unexpected tax consequences in Jessie Lee Edwards. ${ }^{145}$ There was an equal division of the community property, but the wife "was insistent on receiving cash for her share of the community property. She was inexperienced in business and wanted to assume as little business risk as possible." ${ }^{146}$ Accordingly, she received $\$ 40,000$ in cash, a note for $\$ 48,000$ and the balance of her $\$ 93,000$ in property from the community. Said the Tax Court:

This transaction did not amount to a partition of each item of community property; it was not a complete liquidation of the community property with a consequent division of the proceeds; neither was it an out and out division of the community property with the wife and husband each taking certain items in kind and of an approximately equal value. ... The settlement agreement amounted to a virtual sale of Jessie's interest in certain of the community assets for a consideration, over and above a inere exchange or division of community property. ${ }^{147}$

1436 T.C. at 913-14.

144173 F.2d 471 (5th Cir. 1949), reversing 16 P-H Tax Ct. Mem. 553 (1947).

14522 T.C. 65 (1954).

14622 T.C. at 66.

14722 T.C. at $69-70$. 
To summarize, there should be no income tax problems on the division of property. Counsel occasionally desire to create a taxable transaction to obtain a stepped-up basis. More often they will seek an equal division of the community with a reallocation of basis. Counsel on both sides must be aware of these tax consequences. $A$ failure to consider them could be disastrous to the husband, the wife, or both..$^{148}$

148 For a comparison of the income tax consequences of property settlements in common-law and community property jurisdictions, consider the following hypothetical illustration: The family unit owns two pieces of property, parcel $X$ and parcel $Y$. Both parcels have been purchased from savings since the marriage of $B$ and $W$. In Jurisdiction $A$, a common-law state, the title to both parcels is held by $H$. In Jurisdiction $B$, a community property state, the title is held by $H$ and $W$ as community property. Under a property settlement agreement, the parties have made the following proposals:

1. That $H$ and $W$ each take $1 / 2$ of each parcel.

2. That $H$ and $W$ divide the property equally, based on fair market value.

3. That $B$ take $X$ parcel and $W$ take $Y$ parcel.

The cost and fair market value of $X$ and $Y$ are as follows:

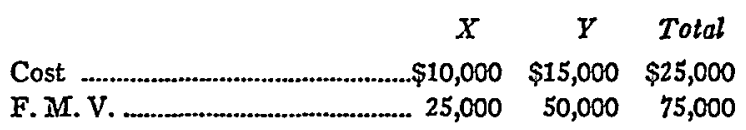

What are the income tax consequences of each of the above transactions in Jurisdictions $A$ and $B$, to $H$ and $W$ ?

I. Jurisdiction $A$ (under Mesta theory)

1. $H$ and $W$ each agree to take $1 / 2$ of each parcel.

a. $H$ would realize gain of $\$ 7,500$ on $X$ and $\$ 17,500$ on $Y$.

b. W would realize gain of $\$ 12,500$ on $X$ and $\$ 25,000$ on $Y$.

c. $H$ and $W$ would each have a basis of $\$ 12,500$ in $I / 2$ of $X$ and $\$ 25,000$ in $1 / 2$ of $Y$.

2. $H$ and $W$ divide the property equally, based on fair market values.

(Assume $H$ transfers $3 / 4$ of $Y$ to $W$.)

a. $H$ would realize gain of $\$ 26,250(\$ 37,500-\$ 11,250)$.

b. W would realize gain of $\$ 37,500$.

c. $H$ would have basis of $\$ 10,000$ in $X$ and $\$ 3,750$ in $1 / 4$ of $Y$; W would have basis of $\$ 37,500$ in $3 / 4$ of $Y$.

3. $H$ keeps $X$ parcel; $W$ takes $Y$ parcel.

a. $H$ would realize gain of $\$ 35,000$.

b. W would realize gain of $\$ 50,000$.

c. $H$ would have basis of $\$ 10,000$ in $X ; W$ would have basis of $\$ 50,000$ in $Y$.

II. Jurisdiction $A$ (under Marshman theory)

1. $H$ and $W$ agree to take $1 / 2$ of each parcel.

a. Neither $H$ nor $W$ would realize gain.

b. $H$ and $W$ would each have a basis of $\$ 5,000$ in $1 / 2$ of $X$ and $\$ 7,500$ in $1 / 2$ of $Y$.

2. $H$ and $W$ divide the property equally based on fair market values.

(Assume $H$ transfers $3 / 4$ of $Y$ to $W$. .)

a. Neither $H$ nor $W$ would realize gain.

b. $H$ would have basis of $\$ 10,000$ in $X$ and $\$ 3,750$ in $1 / 4$ of $Y, W$ would have basis of $\$ 11,250$ in $3 / 4$ of $Y$.

3. $H$ keeps $X$ parcel; $W$ takes $Y$ parcel.

a. Neither $H$ nor $W$ would realize gain.

b. $H$ would have basis of $\$ 10,000$ in $X ; W$ would have basis of $\$ 15,000$ in $Y$. 


\section{Treatment as a Partitioning with Reallocation of Basis Where}

Exchange Between Spouses Pertains to Property of Like Kind

Section 1031 of the Internal Revenue Code provides for the nonrecognition of gain or loss where property "held for productive use in trade or business or for investment ... is exchanged solely for property of a like kind to be held either for productive use in trade or business or for investment." On occasion counsel may use this section to avoid recognition of gain or loss even though separate property is involved or there is an unequal division of the community property. Care must be taken to segregate those assets that will be exchanged under this provision. In this type of exchange, the parties acquire a substituted, rather than a transferred, basis. If allocations of basis are required, they will be based on relative fair market values, rather than bases. For example:

Assume that $H$ and $W$ own three pieces of property:

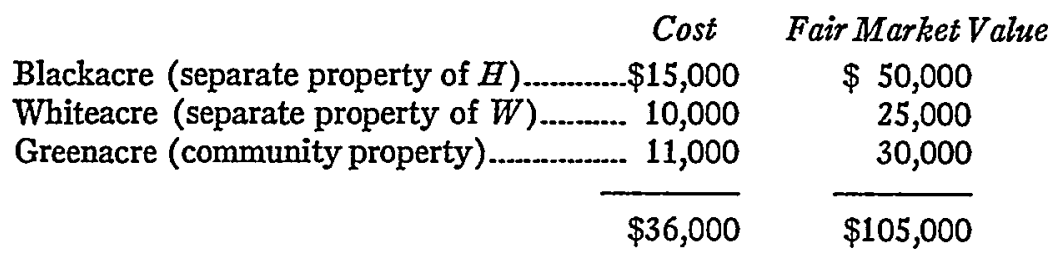

All of these properties are of like kind and are held for productive use in trade or business or for investment. In a property settlement, $H$ and $W$ agree that $W$ should receive two-thirds of the total of fair market value (i.e., property worth $\$ 70,000$ ), and that $H$ should receive one-third (i.e., property worth $\$ 35,000$ ). They first divide the community property on this ratio. $H$ then transfers an undivided four-fifths interest in Blackacre

III. Jurisdiction $B$

1. $H$ and $W$ each agree to take $I / 2$ of each parcel.

a. No taxable gain to either $H$ or $W$.

b. $H$ and $W$ would each have a new basis of $\$ 5,000$ and $\$ 7,500$ in $X$ and $Y$.

2. $H$ and $W$ divide the property equally, based on fair market value.

(Assume $H$ takes $X$ plus $I / 4$ of $Y ; W$ takes $3 / 4$ of $Y$.)

a. No taxable gain to either $H$ or $W$.

b. $H$ has new basis of $\$ 9,090$ in $X$ and $\$ 3,410^{*}$ in $I / 4$ of $Y$; $W$ has new basis of $\$ 12,500$ in $3 / 4$ of $Y$.

3. $H$ takes $X ; W$ takes $Y$.

a. $H$ realizes gain of $\$ 5,000(\$ 12,500-\$ 7,500)$.

b. $W$ realizs gain of $\$ 20,000(\$ 25,000-\$ 5,000)$.

c. $H$ has a new basis of $\$ 17,500$ in $X ; W$ has new basis in $Y$ of $\$ 27,500$.

* Allocation based on cost. Allocation of basis based on fair market values would produce $\$ 8,433$ for $X$ and $\$ 4,267$ for $\mathrm{T} / 4$ of $T$. 
to $W$ in exchange for an undivided three-fifths interest in Whiteacre. After the exchange, $H$ and $W$ own:

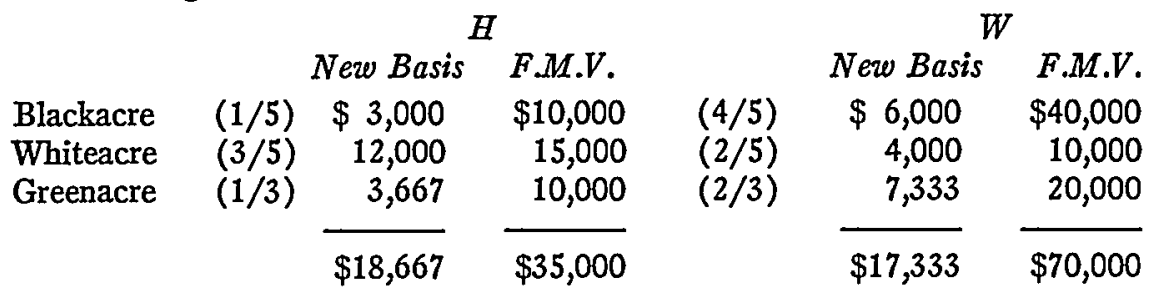

Other solutions might be worked out, depending upon the parties' desires with reference to particular pieces of property.

\section{IV}

\section{USE OF TRUSTS AND INSURANCE}

Lawyers who plan property settlement agreements often find it desirable to use existing trusts or insurance policies. Occasionally they may have the parties establish new trusts or purcliase additional insurance. In all such plans, care must be taken to avoid tax traps peculiar to these devices.

\section{A. Trusts}

1. Trust Not Created in Contemplation of Divorce; Income That Was Taxable to Husband Now Taxable to Wife

Where a trust is already in existence, the parties usually find it convenient to provide in the decree that the income shall be payable to the wife. In that event, the inconie from the trust following the divorce is taxable to the wife, notwithstanding that it would normally be taxable to the husband. ${ }^{149}$ If the decree provides that a portion of the income from the trust is to be used for the support of minor children, such an amount will continue to be taxable to the husband..$^{150}$

\section{Trust Created in Contemplation of Divorce}

Where a trust is established in contemplation of divorce it is often provided that the wife will receive a fixed amount periodically and that the trustee may invade corpus to satisfy this amount. In such event, the wife realizes income up to the fixed amount, even though there may be insufficient trust income to cover the payment. ${ }^{151}$ The husband neither realizes income, nor is he entitled to any deduction by reason of this payment. 
This result may be avoided by providing in the agreement that where the trust income is insufficient to cover the amount of the periodic payment, the husband shall make up any deficiency from nontrust sources. This will preserve the trust corpus and provide a deduction for the husband for any additional amount that is required.

\section{B. Serious Disadvantages in Transferring Insurance Policies as Part of Property Settlement}

Prior to divorce the husband usually will have been paying premiums for insurance on his life out of community funds or his separate property, and will have retained all incidents of ownerslip (e.g., the right to change the beneficiary, borrow on the policy, assign the policy, and the like).

\section{Gift and Estate Tax Consequences}

Normally there will be no gift tax consequences if an insurance policy is used in the property settlement. A transfer of this asset as part of a property settlement will be treated like any other transfer in satisfaction of the wife's right of support and will not be taxable. There will be no estate tax consequences, so long as the husband gives up all incidents of ownership. ${ }^{152}$

\section{Income Tax Consequences}

a. With Regard to the Transfer

Difficulty arises, however, from additional income tax consequences of such a transfer. On the husband's death the transferee wife will realize gain to the extent that the insurance proceeds exceed her basis. ${ }^{153}$ For example:

As a part of a property settlement, $H$ transfers to $W$ a life insurance policy in the face anount of $\$ 15,000$. Prior to the transfer, $H$, using his own separate funds, paid $\$ 3,000$ in premiuns. After the divorce $W$ paid $\$ 2,000$ in premiums. $H$ then died and $W$ collected the $\$ 15,000$ insurance proceeds. $W$ would realize ordinary income in the amount of $\$ 13,000$.

If the $\$ 3,000$ paid by $H$ prior to the divorce were paid out of community funds, $W$ 's gain would be $\$ 11,500$ (i.e., $\$ 15,000-\$ 3,500$ ).

The best practice is to assign each policy to the spouse on wlose life the insurance is carried. The proceeds will be includible in that spouse's gross estate, but this problem may be resolved at a later date after the spouse lias remarried and establislred a new family unit. 
If an even number of policies purchased with community funds are owned by the family unit, they could be equally divided between husband and wife, without regard to who is the insured. Arguably, there would be no "transfer for a valuable consideration" in such an equal division of community property, and the rule of section 101(a) (2) of the Internal Revenue Code would not apply. But since such a division, when considered along with the division of other properties, might be considered a sale or exchange, the better solution is to assign each policy to the spouse who is the insured.

\section{b. With Regard to the Premium Payments}

Despite these tax consequences it is not uncommon for a divorce decree to provide for the assignment of a policy of insurance on the husband's life to the wife and to require that the husband continue to nuake the premium payments. In such a case, the payments are deductible by the husband and taxable income to the wife. ${ }^{154}$ But the husband must give up all economic control over the policy to achieve this result. ${ }^{155}$

Insurance proceeds are often paid out to the beneficiary over a period of time. The total of such payments will exceed the amount that the beneficiary would receive by way of a lump sum. Since 1954 this excess "interest element" has been taxable income. ${ }^{16 B}$ But Congress has provided that the surviving spouse may exclude from gross income $\$ 1,000$ annually of this amount. While the tern "surviving spouse" does not include a divorced wife, it does include one who is legally separated. ${ }^{157}$ Yet even in the latter situation it is doubtful whether this element would be excluded from gross incoine, since the Regulations provide that the wife must pay tax on the payments whether attributed "to life insurance ... or to any other interest in property."

This problem may be avoided by assigning to the wife all rights under the policy, including the option to take the proceeds in a lump sum.

\section{Better Not to Use Annuities in Marital Settlements}

A similar problem arises with annuities. Under section 72 of the Internal Revenue Code an aunuitant excludes from gross income a pro rata portion

154 I.T. 4001, 1950-1 CuM. BuLc. 27. The premiums are not taxed to the wife if she must survive the insured to obtain the proceeds. Smith's Estate v. Commissioner, 208 F.2d 349 (3d Cir. 1953); Leon Mandel, 23 T.C. 81 (1954), af'd, 229 F.2d 382 (7th Cir. 1956); Lilian Bond Smith, 21 T.C. 353 (1953). Cf. Sehgmann v. Commissioner, 207 F.2d 489 (7th Cir. 1953).

155 Baker v. Commissioner, 205 F.2d 369 (2d Cir. 1953) (premium payments, which were security for payment of alimony, held nondeductible); Rev. Rul. 57-125, 1957-1 CuM. Bunx. 27 (no deduction for premium payments even though decree required husband to pay them to maintain wife as primary beneficiary, and required husband not to borrow on pohicy).

156 INT. REv. CODE OF 1954, \& 101(c).

157 INT. REv. CoDE or 1954, \& 101 (d) (3).

158 Treas. Reg. 1.71-1(c) (2) (1957). 
of his cost each time he receives an annuity payment. He continues to exclude this pro rata portion even though he lives beyond his life expectancy and recovers his cost. If he transfers the annuity to his wife, however, as part of a property settlement, the entire annuity payments become taxable to the wife, ${ }^{159}$ and this desirable income tax advantage is lost.

\section{V \\ DEDUCTIBILITY OF ATTORNEY'S FEES}

\section{A. By the Wife}

To gain a tax deduction for legal fees, counsel should arrange the property settlement so that the wife pays her attorney's fees out of her own funds or funds that she receives from the settlement. In Elsie B. Gale ${ }^{180}$ the wife paid $\$ 4,000$ to attorneys for legal services to obtain from the divorce court an increase in the amount of alimony payments provided in the decree. The Tax Court noted that Congress had broadened the deductions allowed to an individual by permitting him to deduct "ordinary and necessary expenses paid or incurred ... for the production or collection of income."161 Alimony taxable to the wife was "income" for the purposes of this section. The expenses were "ordinary and necessary" since the taxpayer had done what was necessary and appropriate to collect such income. No part of them were for the personal marital difficulties of the taxpayer, allocable to nondeductible "personal, family or living expenses."162

In Barbara B. LeMond ${ }^{163}$ the parties settled their financial problems by a New York separation agreement and their marital problems by a Nevada divorce. No contention was made that the legal expenses in connection with the latter were deductible, ${ }^{104}$ but since 80 per cent of the total alimony payable under the agreement was taxable to the wife, ${ }^{165}$ she was entitled to deduct 80 per cent of the legal expenses in connection with it.

159 Ibid. See also INT. REv. CoDE of 1954, § $72(\mathrm{k})$, providing that the annuity rules do not apply to periodic payments taxable to the wife under INT. REv. CODE OF 1954, $\$ 71$ or $\$ 682$.

16013 T.C. 661 (1949), aff'd without consideration of this issue, 191 F.2d 79 (2d Cir. 1951).

161 Int. Rev. Code of 1939, § 23 (a) (2), as amended, ch. 619, §121 (a), 56 Stat. 819 (1942) (now INT. REv. CODE, of 1954, § 212(1)).

102 Int. Rev. Code of 1939, ch.1, § 24(a) (1), 53 Stat. 16 (now INt. Rev. Code of 1954, §262).

10313 T.C. 670 (1949).

104 The Tax Court ruled: "[N]o part of the legal expenses herein constituted personal family expenses and ... no allocation of the legal fees in that respect is necessary." 13 T.C. 670,674 .

$165 \$ 166,200$ of the total alimony of $\$ 213,600$ was taxable to the wife, simce on the facts the installment payment rule himited taxable income in any one year to $10 \%$ of the principal sum. INT. REv. CODE OF 1954, \& 71(c)(2). 
The Treasury has adopted the view of Gale and LeMond ${ }^{100}$ and the Regulations now read:

Generally, attorney's fees and other costs paid in connection with a divorce, separation, or decree for support are not deductible by either the husband or the wife. However, the part of an attorney's fee and the part of the other costs paid in connection with a divorce, legal separation, written separation agreeinent, or a decree for support, which are properly attributable to the production or collection of amounts includible in gross income under section 71 are deductible by the wife under section 212.107

In a community property state counsel should have no difficulty obtaining a deduction for that portion of the wife's attorney's fees allocable to the periodic payments that she nuay be provided. Whether she may obtain a deduction for that portion of the fees allocable to obtaining her half of the community property is less certain. If the expenses are for the recovery of title, they go to increase the wife's basis in the property acquired, but if they are in connection with a conversion of her portion of the community property into liquid assets, she may obtain a pro rata reduction. ${ }^{108}$

\section{B. By the Husband}

The husband will generally be unable to obtain a deduction for attorney's fees, ${ }^{169}$ but a few cases have allowed him the deduction in certain special situations. In Baer v. Commissioner, ${ }^{170}$ for example, he was allowed a deduction for that portion of the fees paid "for services in the negotiations as to form and amount of alimony." transfer stock in a controlled corportion worth $\$ 1,000,000$. His attorneys successfully negotiated an agreement whereby he transferred 4,000 shares,

100 T.D. 5889, 1952-1 Cons. BuLL. 31.

107 Treas. Reg. § 1.262-1(b) (7) (1958).

108 See Agnes Pyne Coke, 17 T.C. 403 (1951), aff'd, 201 F.2d 742 (5th Cir. 1953). In this case $W$ recovered from $H$ property that had a fair market value of $\$ 246,560$ and a basis of $\$ 61,425$ in $W$. The court held that $61,425 / 246,560$ of the legal expenses in connection with this recovery had to be capitalized and that the balance was deductible.

169 Lewis v. Commissioner, 253 F.2d 821 (2d Cir. 1958); Hunter v. United States, 219 F.2d 69 (2d Cir. 1955); Smith's Estate v. Commissioner, 208 F.2d 349 (3d Cir. 1953) ; Estate of James E. Walsh, 28 T.C. 1274 (1957); Thorne Donnelley, 16 T.C. 1196 (1951); Davis v. United States, 287 F.2d 168 (Ct. Cl. 1961), cert. filed on this point by taxpayer July 28, 1961.

170 Baer v. Counnissioner, 196 F.2d 646 (8th Cir. 1952). See also Owens v. Commissioner, 273 F.2d 251 (5th Cir. 1959); Bowers v. Commissioner, 243 F.2d 904 (6th Cir. 1957); Patrick v. United States, 186 F. Supp. 48 (W.D. S.C. 1960) ; Fisher v. United States, 157 F. Supp. 364 (W.D. Pa. 1957); McMurtry v. United States, 132 Ct. Cl. 418, 132 F. Supp. 114 (1955). It is clear that the husband is entitled to deduct a proper allocation for legal fees paid in comection with the determination of his tax consequences by reason of the divorce and property settlement. INT. REv. CoDE or 1954, § 212 (3); Davis v. United States, 287 F.2d 168 (Ct. Cl. 1961).

171196 F.2d 646, 650 (8th Cir. 1952). 
but retained voting power and power of disposition over these shares. The Eighth Circuit held:

[I] $t$ was through ... [ the attorneys'] efforts that the plan was worked out by which he was placed in the position to meet these obligations and yet remain in control of the company and his stock therein. In so doing they were, we think, conserving and maintaining property held by Baer for the production of income. ${ }^{172}$

Recently, the Fifth Circuit announced that it would follow Baer in a case involving a Texas community property settlement. In Owens v. Commissioner, ${ }^{173}$ the taxpayer husband, as part of the settlement, paid the wife's attorney a fee of $\$ 7,500$ to salvage the busmess in which he was a partner. The Fifth Circuit ruled that it would follow Baer, and that the fee so paid was therefore deductible.

While the taxpayer was successful in Baer and Owens, Lewis v. Commissioner ${ }^{174}$ is more typical of the fortunes of the husband in these cases. There, the taxpayer was the author and publisher of several controversial books. By various judicial proceedings, his wife sought to have him committed as dangerously insane, to have hin declared mentally incompetent, to obtain a legal separation, and to obtain an accounting of her property. He paid his own legal fees in defending these actions and his wife's expenses in the separation suit. He also was required to pay the trustee's legal fees when he revoked a trust that was for the wife's benefit and the trustee sought a judicial settlement of its account.

The court held the legal expenses of the mental proceedings personal and nondeductible. The fees for defending the accounting actions were to protect the taxpayer's title and had to be capitalized. In the separation suit the wife's attorneys' fees were not deductible by the husband, ${ }^{175}$ and he could not deduct his own fees since they were personal. The court refused to follow Baer, holding that it was in conflict with the Supreme Court's decision in Lykes v. United States. ${ }^{170}$

In summary, the wife may obtain a deduction for legal expenses in connection with obtaining periodic payments. She should also be entitled to deduct expenses im connection with obtaining her share of the community property, but the Commissioner may argue that such expenses are to protect her title and should be capitalized. The husband may be successful in obtaining a deduction for his expenses. But even if he is successful in show-

172 Ibid.

173273 F.2d 251 (5th Cir. 1959), cert. not sought by Commissioner, 4 P-H 1960 FED. TAX SERV. \I56370.

174253 F.2d 821 (2d Cir. 1958).

175 Based on the rationale of Magruder v. Supplee, 316 U.S. 394 (1942).

170343 U.S. 118 (1952) (legal expenses in contesting gift tax deficiency held nondeductible). 
ing that the expenses are not personal, he may still be required to capitalize them.

\section{CONCLUSION}

Tax problems incident to divorce and property settlement center around the imcome tax. Adverse gift and estate tax consequences have been largely eliminated from this field. On the contrary, the husband's estate tax liability may be reduced by making dependents' claims enforceable against his estate.

With regard to the income tax, it will usually be in the best interests of all concerned to make alimony payments "periodic." In a common-law jurisdiction, no adverse income tax consequences will flow from a lump sum settlement so long as the theory of Commissioner v. Marshman is followed. Similarly, in a community property jurisdiction, such consequences may be avoided by an equal division of the whole community property without a cash transfer from one party to the other. The use of trusts, insurance, and annuities that characterizes the usual estate plan may be quite unwise where the family unit is about to be dissolved. Both parties should pay their own attorney's fees to obtain income tax deductions not otherwise available.

By careful drafting with these considerations in mind, the lawyer will serve his chent as a party to a divorce and as a taxpayer, whether he be average or otherwise. 